\title{
Nothing Profits More: Social Knowledge and National Development
}

\author{
Akin L. Mabogunje \\ Development Policy Centre, Ibadan, Nigeria
}

Let me start by thanking the Executive Committee of the Social Science Academy of Nigeria for the invitation to address this $11^{\text {th }}$ General Assembly of the Academy. The letter of invitation written by the Executive Secretary of the Academy, Professor Layi Erinosho, indicated that the particular concern of this General Assembly is "to take stock of social science scholarship in Nigeria", hence the theme "Reflection on 50 years of Social Science Education in Nigeria ". The letter also emphasized that the purpose of this reflection is to assist social scientists in their different disciplines "to outline the strategies for strengthening social science scholarship by the next millennium".

In reacting to this overarching concern of the Academy, I have chosen as the title of my address: Nothing Profits More: Social Knowledge and National Development. The first part of the title is from Book Eight of Paradise Lost, the epic poem of the $17^{\text {th }}$ century English poet, John Milton. I do not need to go into details of what that epic poem is about but it is important to my address to quote the relevant section from which the first part of my title derives. To quote:

Oft times nothing profits more

Than self-esteem, grounded on just and right

Well manag'd; of that skill the more.thou knaw'st,

The more she will acknowledge thee her Head,

And to realities yield all her show "

(Milton: Paradise Lost, Bk.VIII, 1. 571-575)

It is against the issue of national self-esteem that I have then posed the other two questions in my title, namely what type of 
knowledge have we been producing in the social sciences over these last fifty years? How far have they assisted in meeting the developmental challenges of our country and enhancing our national self-esteem?

I have divided this address into five parts. The first part revisits the concept of development examining the new emphasis on knowledge and good governance as critical element for national development; the second part considers the nature of social knowledge whilst the third examines the Nigerian society, noting the pervasive context of primordial territoriality within which the majority of Nigerians still live and have their being. A fourth part then considers the impact of what I have called the "colonial rupture" on our social, economic and political life and the moral confusion into which this has thrown most Nigerians. The final part then discusses what types of social knowledge we require from the social sciences to assist in consolidating our fledgling democratic governance, nurturing to maturity our emerging free market culture and putting our national development on a path of long-term and sustainable growth. A concluding section looks at the challenges for the social sciences in a country seeking,to democratize and develop in the context of a globalizing world. Revisiting the Concept of Development.

In late colonial and early post-Independence years, the pre-occupation of the social sciences in Nigeria has been with "development", seen largely in the context of "modernization". Development was conceived off largely in economistic or instrumentalist terms as a process of increasing national productivity or the per capita gross domestic product of the nation. To achieve such a remarkable feat against the prevailing poverty, ignorance and disease of the majority of the populace, it was believed by both the political and academic elite that a strong, united nation whose affairs can be guided and directed to move in the appropriate and desired direction was a sine qua non. The nationalist mobilisation against the colonial regime thus translated 
into a new mobilisation for nation-building and national unity under, a "strong", authoritarian government. Given such a stance, the Nigerian post-colonial state denied itself the possibilities of dealing with its inherent social pluralism in a manner that was non-conflictual and emphasized dialogue. Instead, as Mkandawire (1997:18) puts it, "every articulation of genuine local interests, of manifestation of ethnic identity was viewed as almost treasonous and was harshly repressed". Strong government with a populist ideological claims was seen everywhere as the means to foster national development. It could curtail "decision costs" incurred through democratic decisionmaking processes. In the Nigerian context, in the absence of any single political party than could unify the country, the alternative institution was the military. The ideological underpinning of both the one-party or the military-ruled state became one that also posited a false dichotomy between collective and individual rights. Indeed, in support of such ideological stance, there were intellectuals who were prepared to argue that concern with collective or communal rights was African whilst concern with individual rights was foreign. The result was the incredible abuse of power and the tremendous range of human rights violations that came to be assumed as a necessary concomitant of securing the effectiveness of state power to promote development.

Under such regimes, development planning became no more than investment planning. Development plans were produced not to mobilise the society to lift itself up by its bootstraps but to articulate a shopping list of projects to be undertaken. Not unexpectedly, it was the lending agencies, multilateral, bilateral and private as well as contractors of various competencies and nationalities that came to be mobilised. As authoritarian rule became more entrenched everywhere, it paid less and less attention to being transparent or accountable. Over-invoicing of contract awards and various other fraudulent schemes 
became the order of the day. This caricature of national development stalled as the debt overhang grew in volume and relative magnitude vis-a-vis gross domestic production. By the end of the 1970s, Nigeria, like many other countries in Africa, had entered its "lost decade".

As government became increasingly crass and venal, it cared less and less for knowledge. Indeed, the intellectuals who had been quite involved in the nationalist struggle and the immediate post-independence effort with nation-building found themselves no longer welcome in the corridors of power. Their displacement took the form of government's assault on their bastion of academic freedom in the University. That assault was first flagged off by Kwame Nkrumah who in the mid-1960s had protested about the academics in the following words:

We do not intend to sit idly by and see these institutions which are supported by millions of pounds produced out of the sweat and toil of common people continue to be centres of anti-government activities. We want the university college to cease being an alien institution and to take on the character of a Ghanaian University, loyally serving the interest of the nation and the well-being of our people. If reforms do not come from within, we intend to impose them from outside, and no resort to the cry of academic freedom (for academic freedom does not mean irresponsibility) is going to restrain us from seeing that our university is a healthy university devoted to Ghanaian interest (Hagan 1993)

Elsewhere, the assault was specifically directed at the social sciences. Most African governments came to distrust the faculty of the social sciences and saw it as the breeding ground for training student revolutionaries, agitators and anti-government demonstrators. The greatest bile was reserved particularly for the political scientists and, to some extent, the sociologists. Indeed, some Universities were being persuaded to shut down these 
departments. Where they were not shut down, they were allowed very limited or no access at all to research grants. But even those subjects such as economics, psychology and geography which were not so controversial found their research output dismissed out of hand as of no immediate relevance to the task of national development.

Three decades of military rule in Nigeria (and of one-party rule in other African countries) have forced us and our foreign mentors such as the Bretton Woods institutions to start to have a salutary re-think. For one thing, for all of its touted efficiency, neither military rule nor the one-party state made for increased national productivity. For another, even the mentor institutions found that their loans, grants and investments have not brought about the expected economic returns. Where the projects for which loans were granted were completed, they just couldn't be maintained after a few years of operation. Where incompetence, mismanagement and corruption made it difficult to complete projects, the debt already incurred could not be serviced. Like elsewhere in Africa, the debt overhang became a fact of life. A structural adjustment programme was instituted after a fashion but could make very little dent on the degrading social and economic situation. Poverty became the lot of the majority of the populace and conjunctural factors drove most of the middle class into the same quagmire. By 1998, close to 70 per cent of the Nigeria population was said to live in poverty on less than US $\$ 1.00$ per day (UNDP 1998).

In the circumstances, it was not difficult for everybody but especially the mentor Bretton Woods institutions to start to appreciate that development was the product of more than investment planning. The quality of governance, especially the extent to which it was transparent, accountable and democratic, came to be seen as central to real development. This necessitated an almost paradigmatic shift from, as it were, an obsession with growth of commodity production to a deeper concern with the state 
of community ethos and collective responsibilities. The Bretton Wood institutions became the champions of good and non-venal governance and went as far as to include it as conditionally for loan disbursement.

One other development being championed by these, institutions in recent times was the primacy of knowledge as a critical factor in development. Again, according to the World Bank (1999: 25), "successful development entails more than investing in physical capital, or closing the gap in capital. It also entails acquiring and using knowledge - closing the gaps in knowledge." Thus, to successfully confront the challenges of development, a developing country must undertake three major tasks:

* acquire and adapt global knowledge - and create knowledge locally;

* invest in human capital to increase the ability to absorb and use knowledge;

* invest in technologies to facilitate both the acquisition and the absorption of knowledge.

Although the Report made too much economic and technological knowledge much of which needs to be acquired abroad, it did pay a nodding recognition to the need to create knowledge locally. Indeed, it can be argued that if governance were to become as central to development as knowledge, then the more we know of our society and what facilitates and expedites its good governance, the more we would have effectively used social knowledge for sustained and sustainable national development.

\section{The Nature of Social Knowledge}

The question can then be asked? What do we know about the Nigerian Society? What type of knowledge do social scientists create that can assist not only with improved governance of the society but also with its enhanced economic development? ${ }^{1}$ Of course, it cannot be denied that we do know a lot about society 
generally, especially in theoretical terms. We know a lot also about economic development especially the received theories about how to promote it. We also know a lot about political behaviours and constitutional arrangements in different parts of the world and to some extent about our own country. Our academic journals are full of articles of all types written in relation to the most recently articulated social theories in our different professional fields and using the most sophisticated analytical techniques to draw out sometimes quite obvious conclusions or inference whose practicality are difficult to test or establish. In short, the question to ask is not just what we know but what type and how useful a knowledge?

In trying to answer this question, I find myself going back to Aristotle and his view on knowledge through the work of Bent Flyvbjerg (1990), a Danish planner. According to Flyvberg, Aristotle distinguished three types of knowledge, each serving a different purpose. The first type is episteme, meaning knowledge that is universal, eternal and can be demonstrated to be true. This term, which is represented in English by the derivative "epistemology" is the ideal of pure science. (Peattie 1995). The second type, techne, also has its English cognate in "technique" or "know-how". It is the knowledge of the art or craft of bringing something into being. The third type of knowledge is phronesis. This has no English derivative but is often translated as "prudence" or the knowledge of what to do in particular circumstances. Aristotle claims that prudence is concerned not only with universals but also with particulars, because its interest is about conduct, and conduct has its sphere in particular circumstances.

On this basis, Flyvbjerg argues for the development of a "progressive phronesis", that is knowledge that focuses on the identification of contextualised patterns that can guide action and serve as models for analysis and analysis-guided policies. To my mind, it is this type of social knowledge that derives from the context of our own societal realities that is critical for greater 
analytical efficacy and more effective social action and socio-economic development in our country. According to Peattie (1995),' social knowledge when conceived as phronesis would constrain us to focus on the following seven methodological issues:

* $\quad$ values - where are we going? Is it desirable? What should be done?

* $\quad$ power - who gains and who loses? By virtue of which mechanisms of power? What are the possibilities for changing existing power relations, if desirable?

* closeness - how intimately close is the researcher to what is being studied and how much is the research embedded in the relevant context whether of contemporary or historical studies?

* minutiae - knowing that small questions often lead to big answers and that details often, when closely scrutinized, are pregnant with metaphor, what are the "small questions", which can serve as points of departure for unraveling a problem and help us focus on thick description of minutiae?

* practices - what do we know of actual daily practices and practical knowledge that constitute given areas of our interest?

* concrete cases - how can we focus on case studies, precedents and exemplars knowing that there is no way of understanding practical rationality except on the bases of in-depth case experience?

* context - how can we understand the proper context in which these practices and cases take place?

It is possible to take each of these issues and ask ourselves how well they are addressed in most of our researches in the social sciences? How well have our research output followed these methodological guidelines such that they can be said to produce really social knowledge, knowledge "that can guide action or serve as models for analysis and analysis-guided policies"? How seriously have we examined the context in which practices and activities go on in the Nigerian society? How well have we ensured that our appreciation and analysis of contemporary situa- 
tions, practices and activities are contextualised in the historical and cultural experience of our people? In the rest of this address, I want to suggest that the failure to be really contextual has been a major factor in the weakness of the social knowledge we have produced so far to promote national development. If we must change the present situation and make social knowledge more impactful on national development, we would need to pay more attention to creating or generating knowledge of a progressively "phrenetic" nature.

\section{The Nigerian Society - The Pervasive Context of Primordial Territoriality}

So, what do we know about the Nigerian society? Every Nigerian can tell you that the society is multi-ethnic, multi-cultural, multi-lingual, multi-religious and so on. These, of course, are static conceptual description. Especially in their interactive context, how do these translate into practices and activities? What institutions undergird their continued significance in our social life and in our national development? How have these been reacting to the challenges of modern times? One indicative factor of the resilience of these institutions are the many conflicts that have characterised the attempts to impact on them as national development moves down to the grassroots. This has been most evident whenever government tampers with such issues as land tenure, local government and chieftaincy rights. The newspapers, for instance, have been replete in recent months with stories of ethnic and communal conflicts of one type of the other. We have had the Zango Kataf incident, the Jema'a Emirate incidents, the Itsekiri-Ijaw-Urhobo incidents, the Ife-Modakeke incidents, the Umuleri-Aguleri incidents and many others of less destructive proportions such as those between the people of Efon Alaye and Aramoko in the former Ekiti South-West Local Government. We are also very conscious of many smaller scale communal disaffection usually over ownership of land. 
In short, primordial territoriality is still a major factor of national life and central to this is the position of land in a pre-capitalist society. In any such society, land is an element of nature inextricably interwoven with man's institutions. Land was tied up with the organizations of kinship, neighbourhood, craft and creed with tribe and temple, village and gild. (Polanyi 1963:178). It underpinned the values cherished by the society. These values have both ethical and philosophical aspects to them. (Mabogunje 1980: 73). On the ethical side, societal values insist that nobody shall be allowed to be destitute. Since land was a key factor of production, every member of society must have access to land. This was ensured through an inheritance law which guarantees that all the children or sons of a man shall have a part of all his movable and immovable property. On the philosophical side, living members of a family are seen as involved in a passage in which they serve as links between previous and future generations. Land belongs to all of these - the ancestors, the present generation and posterity. Present owners of land are thus no more than trustees with rights of beneficial use (or usufruct) as long as, they live. They have no power to alienate the land from the ownership of the family. Thus, no ethnic group in Nigeria traditionally recognises the right of sale of land.

In this regard, it is important to also recognise that land was part of the territory of particular groups. The territorial character of the sovereignty of these groups was not merely a matter of sentimental attachment to land but of massive facts permeating all aspects of economic and political conceptions. Ownership of land in any of these territories was, for instance, a measure of allegiance to the sovereign of that particular polity. It was inconceivable that land could be alienated to the member of another ethnic or sub-ethnic polity whose sovereign could at any time be at war with each other. Indeed, even when as a result of conquest, the indigenous sovereign is displaced, the new dominant simply acquired the responsibility for maintaining the territorial integrity 
of the people and their land. In northern Nigeria, for instance, when the Fulani conquered the Hausa states, they had to invoke the islamic • Maliki law to impose a new dispensation on land ownership which allowed the conqueror certain rights over the land of the conquered.

It is important to stress the integrative principles that undergird such economic and political conceptions of society to appreciate the problems still confronting our national development. Principally, those principles all derive from kinship relations. It was kinship that defined access to all factors of production, whether land, labour, capital or entrepreneurship. Kinship determined the residential location whether in the urban or the rural areas. Kinship determined the claims to the labour of one's children or brothers or relatives. Kinship determined the craft skills one can acquire and which one can engage in and kinship often defined those from whom one can expect to raise a loan or credit without the moral hazard of interacting with moneylenders. M.any of the institutions which provide the context for the life and work of the majority of Nigerians are thus institutions that belong to our pre-capitalist past and that are still largely governed if not by the principles but certainly by the value suppositions of kinship relations.

I was not aware of how pervasive and deep these primordial contexts still are in our national life until I was confronted by two situations in the course of my career. The first was in 1957 when I was engaged in field research on rural economy and rural settlement in Egba Division of Ogun State. (Mabogunje 1958). I had stumbled on to a village community and a farmer whose farm was the most degraded I had seen for some time. When I enquired from him how come his farm was so overworked and degraded, he took time to explain to me that this was because he did not originate from the Egba township on whose land he was farming. The Egba township system he was referring to had been destroyed over 150 years before 1957 but its 
organisation and land tenure system still cast strong shadows on ownership and practices in our times.

The second situation occurred when I was saddled with the responsibility of establishing the new system of community banks. We had tried to design a banking system that would use community sanctions as against the market sanctions of the sale of a collateral in case of default to repay loans from the bank. We had then tried to find out the community structure of local governments in the country. It was interesting to discover how much alive and robust these institutions still were in many parts of the country. In northern Nigeria, they have been overlain by the Fulani administrative organisational forms of dagache (village area), hakimi (district) and gari (town). Among the Igbos, the obodo comprising five, six or seven villages was still the basis of community alignments. Among the Yoruba, the ilu was still a major organisational form. In different parts of the country, these various societal organisations have managed not only to preserve many of their institutions but also to transform some of them to meet the challenges of modern life. Perhaps the most important of the transformed institutions is that of the "development associations" or "hometown voluntary associations" or "town unions". These organisations have emerged in the process of colonial migrations away from the hometown. They have become important instrument for bringing modernisation back to the hometown in the form of schools, churches, mosques, clinic, post office, improved roads, water supply system and even electricity built by levies, contributions or donations of sons and daughters of the town especially those that have made good in metropolitan centres of the country.

The point I wish to stress is that we do not know enough of what is happening to all of these traditional institutions. The community structures which I described above were, for instance, are not found in this manner in the Tiv area of the country. It is also not found among many of the minority ethnic groups where 
the word "clan" is used in a somewhat loose manner to describe the communities. I am, of course, not hankering after more ethnographic study. Rather, it is to stress the importance of knowing how the people have been using their various institutions as social capital to negotiate the many changes and challenges of modern times. The expectation is that, if possible, we can further capitalize on this social knowledge to enhance the quality of governance, equity and economic development in different parts of the country. Such knowledge may also enable us to better appreciate the root of value systems that need to be changed to make it compatible with the dictates of modern times. Nonetheless, in order to appreciate the nature and essential features of the changes that modern times demand, it is important to review the implications of the "colonial rupture" of traditional Nigerian societal life and what this portends as we move to the $21^{\text {st }}$ century.

\section{The Implications of the "Colonial Rupture"}

The colonial subjugation of Nigeria starting from 1900 onwards marked a major shift in the trajectory of societal development in Nigeria. It is claimed in some quarters that there is no reason to keep harping back to that experience forty years after the country had gained its political independence. There are, however, four reasons why any discussion of social knowledge in Nigeria cannot ignore that experience. The first is the importance of recognising the ultimate purpose of the colonalisation of Nigeria. This was an attempt to integrate the country into the global capitalist economy. Capitalism is a mode of production organised on the basis of very different social and economic integrative principles than characterised traditional society in Nigeria. The second reason is that this colonial experience greatly determined the direction and pace of institutional changes among the different groups that make up the Nigerian society. Third, appreciating the import of that experience enables us to realise what still requires to be done and what knowledge we still require 
to possess to ensure that our society gets the full advantage of the ongoing economic transition into which the colonial experience had propelled our society. Fourthly, and perhaps most importantly, re-visiting this colonial experience enables us to put in proper perspective the political deprecations of capitalism as an ideological and social system.

Within the social sciences, Marxian interpretation of societal evolution fostered an analytical frame which emphasized the class structure of society and the class struggle arising from the exploitative relations between owners of capital and labour in a capitalist society. Our colonial experience was over-dramatized within this analytical frame such that we fail to appreciate the concrete reality of what a capitalist society is and how limited had been the effort of the colonial administration in transforming our society into one. Indeed, the present underdeveloped state of our society arises precisely because the colonial administration left it still largely entrapped in a transitional state where it is no longer thoroughly pre-capitalist and it is still far from being a fully^ fledged capitalist society.

To appreciate the essence of capitalism, we must conceive of a society where every factor of production, whether land, labour, capital or entrepreneur ship, is treated as if it were a commodity which is given a price tag so that it can be brought to a free, selfregulating market. Capitalist society is thus one in which everything has a "capital" or exchange value which is subject to the principle of supply and demand. In such a society, one must distinguish between "use" and "exchange" value. An asset such as land can thus have a very high use value in that it is very productive. If, however, it cannot be sold or alienated, it has no exchange value and its capital or economic worth is greatly circumscribed. A price-setting and self-regulating market for land, labour, capital and entrepreneurship thus provides the most important integrative mechanism for a capitalist economy and for a capitalist society. 
A basic principle of social life in a capitalist society is the centrality of individual ownership rights. Instead of the dominance of communalist control and ownership, capitalism requires that social assets such as land, labour, capital and entrepreneurship should be owned by individuals and their rights to sell or alienate their individual assets in a functional market should be unfettered. Thus, land in a capitalist society must be individually owned. This means that its boundaries must be surveyed, its area established, its title defined and registered by government so that market transactions in land can be undertaken without difficulty. By the same token, an individual is prepared to put out for sale (determined as wage or salary) part of his mental and physical capabilities for a given number of hours each day. Similarly, he can allow his capital or financial resources to be used by others for a fee defined as interest charges or he can use his entrepreneurial initiative to promote an innovation for which the market is prepared to pay by way of ample profit. Two other consequences followed on the individualism promoted by the free, self-regulating market. One is the urge to improve on the value of the various assets or factors of production; the other is the new importance of contractual relations in social life. The impact of the market on social life is seen in the way individuals strive to increase the productivity of their land, to develop technology to enhance the productivity of their labour, to use capital more efficiently or to organise their enterprise in such a way that it yields more abundant profit. With respect to the contractual basis of social life, instead of the indulgent condonation of infractions that is typical of kinship relations, a breach of contract is visited with prompt and often mutually agreed penalty.

This broad-stroke characterisation and value system of a capitalist system when put against the present situation in Nigeria emphasizes both how limited has been our transition to a free market economy and how much our society still needs to be transformed to make us host to the wealth-generating capabilities 
of societies which have made the full transition. Our colonial experience could thus be seen as a major rupture in the trajectory of our societal development. It has certainly pushed us out of the pre-capitalist on to a capitalist path. But there is enough evidence that the colonial administration could not undertake nor was it in its interest to promote our transformation to a full-fledged capitalist society.

This limitation of our societal transition is evident, for instance, in the fact that the land on which the majority of Nigerians in our rural areas depend remains trapped in the web of pre-capitalist tenure system with all the value implications of that situation. It is also evident in the cavalier manner many Nigerians still treat contractual relations such as those between employers and employees, between lender and borrower of credit or between government and the governed. Moreover, the inability of the majority of rural Nigerians to provide their land with exchange value so as to more easily access credit to improve their productive capabilities is, no doubt, a major factor in the pervasive poverty of our rural areas.

But perhaps the most serious consequence of the colonial rupture and its uncompleted transition is the moral confusion that it inflicted on our society. In place of traditional self-confidence, our people were reduced to a state of imitative dependence, a highly degraded state associated not only with an inability to promote self-reliant economic development but also with the loss of cultural and psychological integrity. As Polanyi (1963: 157) perceptively observes:

Not economic exploitation, as often assumed, but the disintegration of the cultural environment of the victim is the cause of the degradation. The economic process may, naturally, supply the vehicle of the destruction, and almost invariably economic inferiority will make the weaker yield, but the immediate cause of his undoing is not for that reason economic; it lies in the lethal injury to the institutions in which his social existence is embodied. 
The result is loss of self-respect and standards, whether the unit is a people or a class, whether the process springs from so-called 'culture conflict' or from a change in the position of a class within the confines of a society.

The extent of this moral confusion in Nigeria is perhaps best captured by Peter Ekeh (1975) in his paper on the existence of two "publics" in Nigeria to which most Nigerians have to relate almost simultaneously. One public, according to him, belongs to a state-created civic realm. This public tends to be a-moral, has no strongly positive value-system and fosters little sense of social accountability. The other public, belongs to our historically developed 'primordial' realm, the public of our different communities where morality, trust, self-esteem and social accountability are strongly articulated and entrenched. - The moral confusion arising from operating simultaneously in these two publics is well exemplified in the sumptuous receptions which communities often accord their sons and daughters after they have been "kicked" out of government for corrupt or fraudulent practices. Consequently, a major challenge of dealing with the colonial rupture to our societal evolution is how to develop forms of governance which would end this parallelism, integrate the two systems and, as much as possible, build on institutional structures with which the majority of the populace are familiar. This is to nurture among the citizens all of those virtues that make for strong and accountable democratic governance and deepen and strengthen the operations of a free market economy whilst preserving and strengthening a strong sense of our cultural and historical identity. Consolidating Democratic Governance and Free Market Culture.

As we contemplate the future of our national development, therefore, we in the social sciences need to give serious thought on how to use social knowledge to propel the changes required. I have already emphasized that more than ever before there is a profound appreciation that real development cannot take place outside of a governance system that is transparent, accountable and 
participatory and, to that extent, moral. Real development to be sustainable must also be equitable in the sense of providing a level playing field for all citizens through investing in their ability to acquire, absorb and use knowledge effectively. Consequently, it can be asserted that the greatest challenge facing the Nigerian nation on the eve of the new millennium is how to consolidate democratic governance and deepen the free market culture among its citizens so as to make the nation highly competitive in the emerging global environment? Fostering at all levels of our society cultural values appropriate to such consolidated democratic governance through generating the critical phrenetic knowledge is perhaps the most important challenge facing the social sciences in the next millennium. The point to stress is that social knowledge is not meant to be restricted to the elite circle. It is knowledge which must empower and mobilise the majority of the nation's population and induce them to act in ways compatible with the goals of national development. Such knowledge must thus be of a type to which they can relate and which have meaning in the context of their social existence and practical experience.

How then do we do this? In attempting to answer this question, I am reminded of a portion of the Report of the Commission on Higher Education in West Africa (otherwise known as the Elliott Commission) which was presented to the British Parliament in June 1945 and which tried to make a case for establishing a University in West Africa. According to the Report (Colonial Office 1945:18):

The West African's enormous zest overflows into songs as it does into his elaborate organizations and rituals, whose language we have scarcely begun to decipher, which the rest of the world will never decipher, and whose lessons it will never read, without African tuition. Every now and then one comes on flashes which would light up much of our own forgotten history if they could but be made to last. Ancient European or Asiatic legends have counterparts, alive and vigorous, governing the lives of many 
African peoples today. There are many things in West Africa still only half understood. The broad sandals of certain chiefs, for instance, made broad so that the ruler's foot shall not touch the earth at any point; the earth, it is said, is very strong and the ruler very strong, and if these two strong things touch, the current will 'short', so to speak and the power will be lost. Where this custom is followed, if a chief has to be deposed, his dandals are simply taken away and then his foot touches the earth, power is no longer stored in him, and strength is gone. The conceptions behind this -and so many other beliefs - have still to be unravelled. Africa is one of the source continents, and can strengthen our age: though mishandled, it can certainly weaken it. To clear the channels of though and of confidence between Africa and the Western world may well be to open a reinforcement of the spirit of which both may stand greatly in need in the years ahead of us.

This quotation makes it possible to identify four ways in which we, as social scientists, need assiduously to work in order to ensure that the social knowledge that we generate can bring tremendous value to our nation's effort at self-reliant development. First, there is the need for us to go back to trying to identify, investigate and try to understand the many features, rituals, social organisations and institutions of our incredibly numerous ethnic entities. This is partly to educate ourselves about their similarities and differences but equally to "tuition the rest of the world and, maybe, help lighten up much of their own forgotten history". This effort should be seen as more than ethnographic. It is an attempt to unlock much in our own history and culture. For instance, most Yoruba have turned their back on one of their most significant cultural heritage - the Ifa Corpus, on the grounds that it is a reminder of their so-called pagan past. Its divination claims challenge their Christian or Islamic beliefs. Yet, one of the most intriguing aspects of that Corpus is the binary basis of the corpus. How could a non-literate, apparently non-numeric culture come to 
depend on organising its corpus of knowledge on a binary numeric systenvof $2^{8}$ ? Our emphasis in this new effort should be on how to generate knowledge that is both interpretative and comparative. Interpretative in the sense that we try to seriously understand what our societies were trying to achieve through those cultural facets and comparative, in the sense of examining how different ethnic groups in our society designed structures to meet comparable challenges.

A second area of social knowledge at which we should work is the appraisal or evaluation of the very dynamic changes which different ethnic groups have made to their institutions and cultural facets to meet the challenges of modern times. Some of the most notable transformation have taken place in such institutions as land tenure, family formations, family relationship, celebration of life-cycle events such as betrothal and marriages, craft organisations, rural labour mobilization, systems of skills acquisition and credit provisioning. A most notable instance of such dynamic institutional change is in the area of governance. For many communities, the hometown voluntary associations have become the informal but real local development administration with their impressive track record of infrastructural development $i$ and their capacity to mobilised the community for various collective action. We need to know more about such transformed traditional institutions and cultural facets to see how well they can assist in promoting our new concern with democratic governance, equity and economic progress.

A third area deserving attention is in respect of what I have called elsewhere “institutional radicalization" (Mabogunje 1991:1992). This involves understanding various deliberate attempts that have been made to promote development through formally adapting traditional institutions to facilitate the effectiveness of particular programmes. A good example is what the colonial judicial process was doing with land tenure in southern Nigeria before the era of the Land Use Decree. Knowing that in 
the modern period, land-can no longer be treated as a non-alienable asset that cannot be sold, the judicial process had to determine under what condition the sale of family land can be validly done. Through case law, it became established that the signature of the head of the family (usually the oldest member) would confirm that the family had in fact agreed to the alienation of the land. This way the traditional institution of land tenure was being "radicalized". The situation would, indeed, have been completed if we had gone on to register all the land-owning families in a community and established the order of their oldest members. Another example of such radicalized institution is the community banking system which we tried to base on the traditional institutions of "esusu" and the "hometown voluntary association". What we need by way of social knowledge is to appraise these various institutions to see how effective they have been in mobilising the population in desirable directions, what made them most successful in this respect and what lessons we can learn from these experiments for use in other similar circumstances.

Finally, there is the fact that there is still much of modern democratic governance and the full operations of a free market economy that we do not know about. There are, in particular, institutions of the free market economy which we still need to establish in our society to make our economy more robust and to deepen the effectiveness of macroeconomic policies. For example, in respect of the nation's capital market, although we have a fairly well developed market for equity securities in which people are trying to buy into the ownership of various companies, we have hardly developed our bond market in which people are simply lending money for various capital development through the market. Many reasons account for this. Our focal governments are hardly empowered to know how to use the capital market to help with their infrastructural development. Government is still to encourage the full emergence of real estate companies which would take on most of the provision of housing, office and factory 
buildings and various other constructional works in a manner to constitute critical engines of economic development in the country. We are still to establish institutions which will help mobilise the artistic and technological creativity of our people, enhance their property rights to the products of such creativity, assist with their commercialization and develop ways and means to harness their economic benefits.

The point to stress in all these is that even the most technical achievements have to be embedded in a social context for their full value to be enjoyed by a people and for their knowledge to come to serve phronetically as a guide to action. The four categories of intellectual activities which I have identified above provide, to my mind, adequate contextual anchorage for ensuring that the knowledge generated serve their social purpose. These four categories demand that the social sciences seek to provide deeper and interpretative knowledge of our traditional institutions, cultural forms, usages and values, critical knowledge about informal adaptive institutions, cultural forms, usages and values that we have developed in the dynamic process of coping with the challenges of modern life, evaluative knowledge of formal attempts by government to adapt our institutions, cultural forms, usages and values for more effective governance and economic advancement; and promotional knowledge of institutions, cultural forms, usages and values of full-blown democratic governance and free market economy to which we are aspiring as a people.

\section{Conclusion}

Let me conclude this address by recalling that a paramount objective of this session of the General Assembly of the Social Science Academy of Nigeria is "to take stock of social science scholarship in Nigeria ..... with a view to outlining strategies for strengthening it by the next millennium". I believe I have said enough to indicate why social science scholarship has not been as effective as it could be in the affairs of our country during the past 
fifty years. I have also tried to indicate how we can make it a lot more relevant and effective in the next millennium. That millennium is already being characterised as "the globalization era", an era in which the tremendous advances in information technology is impacting on global relationship, bringing nearer each day a realization that the world is fast becoming "a global village". In another sense, however, globalization is the result of the global extension of the capitalist mode of production with its . tremendous wealth-creating potentialities as well as of the increasing concern with the heavy pressure which this mode of, production wantonly and inadvertently puts on the environment, leading to the emerging global movement for "sustainable development".

Whichever way we care to conceive of the era of globalization, one of its most distinguishing emergent features is the growing intensity of competition which it fosters among nation- states. Because of the increasing importance of transnational corporation and foreign direct investment for the economic development and prosperity of nationstates, creating and sustaining the conditions that are likely to attract them become critical factors in the competitiveness of nation-states. Such conditions relate to the quality not only of infrastructural development and environmental conditions but also of democratic governance and political stability in the country. They also depend not only on the minority of elite but on how well the totality of the population is mobilised and organized to give competitive strength and effectiveness to the country. Such mobilization and organization are bound to depend increasingly on the quality of the social knowledge that we possess to promote such a national venture.

Consequently, globalisation is putting greater and greater emphasis on the relation between the state and civil society in determining the international competitiveness of individual nation-states. Apart from the revolutionary impact of information 
technology in this regard, social knowledge is critically needed for empowering civil society to appreciate its rights in relation to those of the state in a democratic context. Nowhere is this more needed than in the increasing societal concern about human rights, the status of women and the quality of the environment. What do our society think about these issues? How have their thoughts been changing? What more can be done to change them in desirable directions? Enhanced social knowledge should not only seek to help answer these questions but also use these answers to further empower the growing number of voluntary, non-governmental organizations. These organizations are the agencies whose role is to catalyze, mobilize and give directions to civil society whilst they also ensure that the State is made more responsive to the felt needs and interests of the society at large. They need social knowledge to enhance their capacity for making it increasingly difficult for the State to put issues such as those of equitable income-distribution, poverty alleviation, employment generation and housing provisioning for the vast majority of the population in the back-burner of its attention. They also need social knowledge to promote democratic culture in the society at large and nurture a concern for transparency and accountability of those in power.

As we move into the new millennium, it is clear that the social sciences in Nigeria already have their tasks well cut put for them. These tasks revolve around helping to produce the social knowledge not only to restore the social and economic health of our nation but also to re-invigorate our individual and collective self-esteem as a people with our own distinctive heritage of history and culture. Such re-invigorated self-esteem can only be initiated through the increasing self-confidence and research output of our scholars and scientists. Indeed, for our national development, nothing can profit us more than investing heavily in such a process of knowledge creation and acquisition. The outcome of such investment is the promotion in our country of a style and system of governance that will be patently 'just and right' and the systematic 
acquisition and absorption of skills which can enable us to properly dominate the realities and difficulties of our environment.

Such heavy investment in studies and researches can, however, be provided only by government and philanthropic organizations. In Nigeria, one hopes that the new government would show a more enlightened understanding of the critical importance of funding quality education and quality research. With the many social scientists in that government, one would hope this should not be too difficult. Philanthropic disposition among our wealthy citizens is one which the social scientists themselves have a role and a duty to promote through enlightenment as to the more enduring nature of such purposeful financial commitments to the development of the nation. Providing the resources, however, is one thing; getting real value for money is another. Greater rigour is needed in most of the social science researches undertaken in the country today. Given the decay and decline that has befallen most of our academic institutions, I believe social scientists can borrow a leaf from the mathematicians and seek funds for initiating a series of summer institutes for advanced training in research methodology, conceptual analysis and theory formulation. Such institutes will be concerned with the retooling of both junior and senior social scientist and will be conducted by eminent scholars from within and outside Africa. This, for me, is perhaps the most critical of the many possible strategies that the Social Sciences Academy of Nigeria can promote to strengthen the social sciences in the new millennium. I wish the Council great success in its challenging leadership role and thank you all for your attention.

\section{References}

Colonial Office (1945) Report of the Commission on Higher Education in West Africa, London, Cmd.6655. 
Ekeh,"P. (1975) "Colonialism and the two Publics in Africa: A Theoretical Statement", Comparative Studies in History and Society, 19(1): 91-112. '

Flyvbjerg, B. (1990) "Aristotle, Foucault and Progressive Phronesis: Outline of an Applied Ethics for Sustainable Development”, in Earl R. Winkler and Jerrold R. Coombs (eds.), Applied Ethics: A Reader, Oxford: Blackwell Publishers.

Hagan, G. (1993) “Academic Freedom and National Responsibility in an African State”, in M.Diouf and M.Mandani (eds.) Academic Freedom in Africa, Dakar: CODESRIA

Mabogunje, A. L. (1958) Changing Pattern of Rural Settlement and Rural Economy, Egba Division, Southwestern Nigeria, Unpublished M.A. Thesis for the University of London, 1958.

Mabogunje, A. L. (1980), The Development Process: A Spatial Perspective, London: Hutchinson University Library.

Mabogunje, A. L. (1991) "Traditional Institutional Radicalization as a Development Strategy", Ibadan Socio- Economic Group Occasional Paper Series, No. 1, December.

Mabogunje, A. L. (1992) “A New Paradigm for Urban Development”, Proceedings of the World Bank Annual Conference on Development Economics 1991, Washington D.C.: World Bank, 191-208.

Mkandawire, T. (1997) "The Social Sciences in Africa: Breaking Local Barriers and Negotiating International Presence", African Studies Review, 40 (2), September.

Peattie, L. R., (1995) “An Approach to Urban Research in the 1990s", in Richard Stren with Judith K. Bell (eds.) Urban Research in the Developing World, Vol. 4: Perspectives on the City, Toronto: University of Toronto, Centre for Urban \& Community Studies. 
Polanyi, K. (1963) The Great Transformation: The Political and Economic Origins of our Time, Boston: Beacon Press, Fourth Printing.

UNDP (1998) Human Development Report 1998, New York: UNDP.

World Bank (1999) World Development Report: Knowledge for Development, (New York: Oxford University Press.

Text of a keynote address delivered at the 11 General Assembly of the Social Science Academy of Nigeria held at the Women Development Centre, Abuja, July 5-7, 1999 on the theme: Reflection on 50years of Social Science Education in Nigeria)

Professor Akin L. Mabogunje, is the Executive Chairman, Development Policy Centre, Ibadan 